\title{
INFILTRATION of SHIA: SEGMENTATION of AL-DAKHIIL in INTREPRETATION of AL-MISHBAH
}

\author{
Afrizal Nur \\ Fakultas Ushuluddin UIN Suska Riau \\ Afrial.Nur@uin-suska.ac.id
}

\begin{abstract}
M.Quraish Shihab is the Indonesian contemporary Muffassir, since he is capable and too bold to convey the message of the Qur'an that's contextualized with the current situation which makes him popular, but at the same time his popularity started dropping as his pro-Shia views and interpretation, this has caused controversy among public. Shia infiltration is a segmentation of al-Dakhiil in the interpretation of the Koran, which is about the following issues: the cult of the Prophet Muhammad's daughter (Fatima ra), Ali bin Abi Talib ra is First People who substitute the Prophet, believer in verse 105 of al-Tawbah letter are special people and Ahlul Bait. Among criticisms, there were always directed to the professor in Qur'an Tafseer at UIN Syarif Hidayatullah Jakarta is a rational interpretation in some cases above, because it is so memorable to his figures of contemporary Shi'ism. Hopefully, this article is as an effort to repair and may contribute to restore al-tafseer book of Mishbah commentary be dignified and highvalue tafseer equivalent to the works of previous commentary of Indonesian Mufassir.
\end{abstract}

Keywords: Shia, Interpretation of al-Mishbah, and al-Dakhiil

\section{Introduction}

Al-Qur'an is the main source of Allah Almighty and the teachings of Islam. Al-Quran is a guide at once an inspiration for every servant of God who studied, studied and understood through interpretation activity. This is a proof of how al-Quran will never be matched by any other works.

Interpreting the Qur'an is a systematic effort and methodology that are carried out continuously to understand the Qur'an, as there is with bi al ma'thur or with bi al ra'yi. The activity of Qur'an interpretation has been started since the period of Prophet Muhammad. After the time of the Prophet and his companions, the activities of interpreting al-Qur'an continued in the days of tabi'in, tabi'tabi'in so up to the time of this era of modern scholars.

M. Quraish Shihab is a contemporary muffassir who brought textual teachings of Qur'an. However, from the aspect of his involvement in tafseer, he included a mufassir who has textual and contextual paradigm of thinking and it can be said that the moderate traditionalist group, because he was grounded in the real Qur'an manuscripts before being contextualized with social reality.

Interpretation method used by M. Quraish Shihab is a rational method (al-ra'y) with mawdu' $i$ approach, because when interpreted Qur'an, he used many sociological, anthropological, historical approaches, mahupun science, this case is required while is not contradictory with the texts of the Qur'an and hadith.

In expressing ideas, his opinions and ideas will certainly bring diverse responses Similarly, there are pros and cons, there is support and the anti, but intellectual maturity makes us mature 
and wisdom so that can accept the diversity of thought and views, but diversity is still in the corridors which do not conflict with the Qur'an and Sunnah, ijma of scholars and other legal sources. Quraish Shihab in this case is an expert as well as muffassir who interpreted Qur'an with a tendency to explore Shia's references.

\section{Al-Dakhiil and Historical Development of Tafsir}

The history review of interpretation of the Qur'an through two fundamental stages, these stages are narration and tadwin :

1. Periodization of Transmission: Al-Qur' an was revealed to the Prophet and unlettered people, do not have the means of expression except circulating from their mouth to mouth, no one understands anything except with their hearts, there is no tradition of writing, but they have eloquence and heart are always maintained as always remembrance. So therefore there has been a deviation among scholars on aspects of Prophet size in interpreting the Koran. Ibn Taymiyah and who agree with him stated: "The Messenger of Allah explains the (alQur'an) to his companions all the meanings of the Qur'an as he described his lafadz, and take proposition from him, while the alKhuwaibi and al-Suyutiy had ideas that: "The Messenger of Allah did not explain the meanings of the Koran verses to his companions except a little.

2. Periodization of Tadwin: This period began at the end of the first Qurun of Hijriyah period, and the beginning of the second Qurun of Hijriyah, in this period of activity of the Koran interpretation of a variety of patterns and types, each with advantages and privileges. Bookkeeping period of hadith got top priority that included various chapters therein. Tafsir is one of the chapters of several chapters covered. At this time the only interpretation contains commentaries of the Quran, letter after letter and verse by verse, from beginning until the end of Qur'an. The attention of some scholars on commentary narration attributed to the Prophet, companions and tabi'in was very high beside the attention of the hadith collection. Leading figure among them in this field were Yazid ibn Harun al-Sulami (d. 117 H), Shu'bah bin Al-Hajjaj (d. 160 H), Sufyan bin Uyainah (d. $198 \mathrm{H}$ ), these are the leading figures of hadith. They make one tafsir become a chapter of the hadith, not an independent science. Imam al-Suyutiy said : "compiled commentaries by collecting words and tabi'een companions, such as Tafsir of Sufyan ibn Uyainah, Waki 'bin Jarah, Shu'bah ibn al-Hajjaj, Yazid ibn Harun, Abdul Razaq, Adam bin Abu lyas, Ishaq bin Rahawi, Run bin 'Ubadah,' Abd bin Humaid, Sa'id Abu Bakr bin Abi Shyaibah and others ".

Meanwhile Muhammad Hussein alDhahabi (1915-1977M) divided the development of interpretation into four Marhalah (stages):

1. The initial Marhalah is the time of the Prophet and the companions.

2. The second Marhalah: Age of Tabiin.

3. The third Marhalah: bookkeeping period ("ushûr al-tadwîn) that began at the end of the Umayyad dynasty and the beginning of the Abbasid dynasty. Dhahabi discussed the time ended when entered the fourth period.

4. Last Marhalah: modern times. He calls these days with the rise of modern science era ('Asr al-Nahdhah al-Ilmiyah al-haditsah) roughly in the latter half of the 19th century.

In the third century, exegesis separated from the science of hadith and made a special science and independent. At that time, the interpretation was managed based tartib mushafi, among the figures who contributed, they were $I b n$ Majah, Ibn Jarir al-Tabariy, Abu Bakr ibn alNaisaburi Munzir, Ibn Abi Hatim, Abu al-Shaykh al-Hibban, al-Hakim and Abu Bakr alMardawaih. The source of interpretation at this 
age is a history of the Prophet, the Companions, tabi' in and atba 'al-tabi'iin, their interpretation were complete from aspects of sanad such as history of hadith. ${ }^{1}$

After this period appearance, the next generation who tried to summarize sanad history, took opinion of scholars before them without mentioning their names. This condition leads to errors and difficult to distinguish between legitimate and dha'if history, as well as the presence of al-dakhiil from elements of isra'iliyyat in widely interpretation ${ }^{2}$. The developments of tafseer continued in line with the dynamics of science, disagreement of opinion appeared increasingly among Muslims and ta'assub to mazhab gave an impact to the science of interpretation. Besides it, the emergence of mahzab of theology and mixing between philosophy and naql science has changed direction of interpretation from the real manhaj. Hermeneutics which used to have its own methods and direction and curreantly has revamped its structure by understanding and expertise of mufassir in specific disciplines of science.

The experts of nahwu (grammar) gave a deep attention to the problem of i'rab, principle of nahwu and disputes of scholars from the cases, the figures were Zajjaj, al-Wahidi, and Abu Hayyan. Al-Qassas focused interpretation by the previous stories without validity test of prior history validity, such as al-Tsa' labi, as well as the perpetrators of heretical spreader and deviant mahzab, they interpreted al- Qur'an to be used as Hujjah for the benefit of their own mahzab ${ }^{3}$. From here, al-dakhiil appear in the interpretation of the Koran until today, it causes some unscrupulous muffassirs who tend to interpret al-Qur'an using sense and do not follow Qa'idah as being

\footnotetext{
${ }^{1}$ Mohd Nazri Ahmad, Isra'iliyyat dan Pengaruh dalam Kitab Tafsir (Kuala Lumpur: Sanon Printing, 2004).

${ }^{2}$ Ibid., 23.

${ }^{3}$ Ibid.
}

predetermined by scholars, we can see this interpretation at the sect Mu'tazailah, Khawarij and the Shia.

The meaning of al dakhiil in language is something that comes and infiltrate from the outside, and not the origin, word of al-dakhiil is used to someone, lafadz and meaning. Among the al-dakhiil material is errors in meaning, hostility, engineered damage, and the mission to boast their nasab. Al-dakhil is a species of bird or poultry, it's called that since the birds are entered in shady trees $^{4}$. Dr. Abdul Wahhab interpreted dakhiil is to interpret the Qur'an with the methods and means taken not from Islam ${ }^{5}$. Al-dakhiil as the terminology is an interpretation that does not have a religious basis, that he entered into the interpretation of the Qur'an al-karim suddenly due to inadvertence against him, and other special factors and the case occurred after the death of Rasulullah saw.

From various opinions that were expressed about the meaning ad dakhiil, the author concluded that the term of ad dakhiil is a virus that goes into the interpretation of the Koran that do not have the basic texts.

Among the factors precipitating the birth of al - Dakhiil, there are two factors:

1. External factors: derived from the enemies of Islam who hold a grudge, they are Jews, Christians, Shia, and other where all of them want the destructions of Islam and damaging its teaching, and bring to the public in a form that is not proper, as a kind of revenge and they bring destruction, such things are to smuggle khurafat stories, lies, falsehoods about al-Qur' an al-Karim, to malign Muslims, making them hesitate to al-Qur'an so that it can separate the unity of Muslims, whereas unity was the main basis taught by the Prophet to his people.

\footnotetext{
4 Syamir Abdul Aziz, 12.

${ }^{5}$ Abdul Wahab Fayyad, al-Dakhiil fi Tafsir al-Qur'an (Mesir: Maktabah Hasan, 1978), 11.
} 
2. Internal factors: transformed into several groups which have the following indicators: affiliation to Islamic groups, but in fact have a very strong connection to the earlier enemies of Islam, the group also has a mission to disrupt the understanding of al-Qur'anul karim, by spreading superstition, falsehood, while their interpretation is the interpretation that contains irregularities and superstition, all of which run neatly in a destructive planning and has been planned by the enemies of Islam from the Jews, Christians, Zoroastrians and others with an agenda to destroy Islam and undermine 'creed and teachings. Allah SWT says (al-Anfal 30):

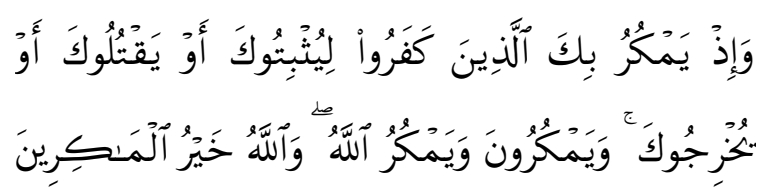

Meaning: "And (remember), when the disbelievers (Quraish) think about their efforts to capture and put you in jail or kill you, or expulse you. They plot and plan, and Allah destructs their plans. and Allah is the best avenger of deceit".

Then Allah destroy their guile and cunning, so that they feel the torment and make their behavior as a result of remorse, as the word of God in as-Shaif verse 8 as below:

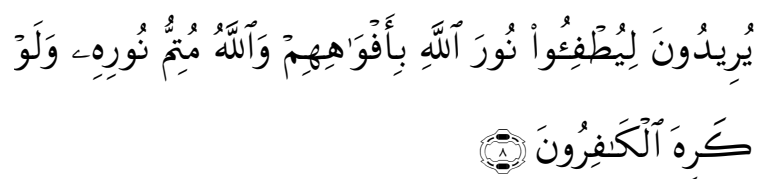

Meaning: "They want to extinguish the light of Allah with their mouths (deceit), but Allah (in fact) make perfect His light, though the disbelievers hate it ".

And Allah has declared his promise to His glorious qur'an to keep and guarantee, as declared in the letter word of Allah al-Hijr verse 9:

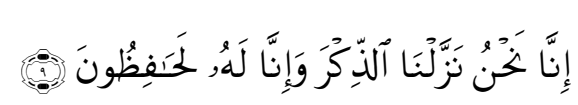

Meaning: "It is We who provided alQur'an, and Truly we really maintain”.

Al-Dakhiil divided into several parts:

1. Isra'iliyyat in interpretation.

2. The hadiths of maudhu', dha'if

3. Bathiniyah Ta'weel

4. Additions of interpretation by "mutashawifah" (expert of Sufism)

5. New cases of interpretation of language matters.

6. Deviations of interpretation from Baha'i and Qadiyaniyah groups.

7. Additions of interpretations done by contemporary commentators who came out of the true meaning of the verse is interpreted and cut some verses of the Koran and perform inferences that do not have a correlation of real meaning.

In the context of this dakhiil, Ahmed Musa Ahmed explicitly Syahaat Dakhiil divided into two categories ${ }^{6}$ :

- Dakhiil bil Ma'tsur; namely the words narrated in the interpretation of the Qur'an by a friend to take away from the scribes, known as Israiliyyat story and not found in our religion that justifies anything. As mentioned by al Qurtuby: from as Suddy and Ibn Jurayj and said:

$$
\begin{aligned}
& \text { إنّه الصّحيح عن ابن مسعود أنّ الذّبيح إسحاق عليه }
\end{aligned}
$$

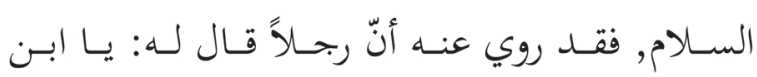

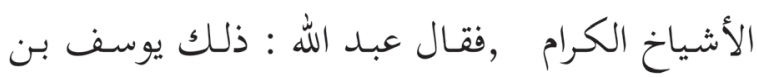

$$
\begin{aligned}
& \text { يعقوب بن إسحاق ذبيح الله, إبن إبراهيم خليل الله }
\end{aligned}
$$

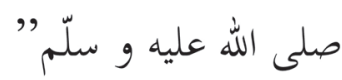

${ }^{6}$ Ahmed Syahaat Ahmed Moosa, Ad dakhiil fii At Tafsiir (Kairo: t.p, t.th), 11-12. 
That is: "What is authentic narrated from Ibn Mas'ud that was slaughtered is Ishaq Alaihi Salam. And has also narrated from him that a man said to him (Abdullah bin Mas'ud): Glorious son of our teacher, and Ibn Mas'ud said: it is Yusuf bin Ya'qub ibn Ishaq was slaughtered by Allah, son of Ibrahim Khalilullah".

Having noted above will be history, explicitly there we can assess all of the text that are shown on story has some similarities with what is owned by a scribe in his book. Ironically, it seems that this story can actually be found in most books of tafseer. An indication that there is blurring of the meaning from the real one.

- Dakhiil bil Ra'yi; namely dakhiil which appears in the tafseer book was based on the interpretation due to thoughts that arise without the support of the interpretation methodology that has been recognized its validity both classical and contemporary by scholars. As performed by al-Zamakhsyari in interpreting the letter al-Baqarah, verse 81:

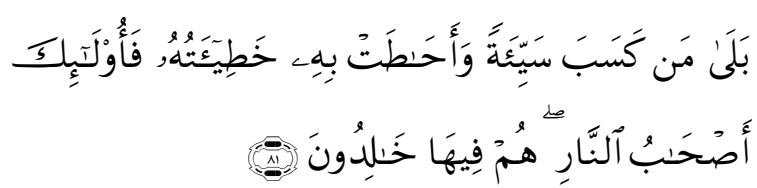

In this verse, Zamakhsyari is trying to interpret the phrase of man kasaba sayyiatan as great sinner who will eternally in hellfire if before the death he did repent. In this case, Zamakhsyari will be inspired understanding of Mu'tazilite ideology that he embraced and believed ${ }^{7}$.

This article will show only one of the seven segments or al-Dakhiil proposed by Syamir Abdul Azizie. additions of interpretation of contemporary commentators, in this case is M. Quraish Shihab that parses side and dimensions of Shi' ism in the interpretation of al-Mishbah.

${ }^{7}$ Ibid., 37.
Shia is flow (firqah) in the treasures of Islamic thought, basically born out of the chaos of the early Muslim people — which remade by Jews $^{8}$. This flow is engaged in politics, science, culture and history, but this flow of new understood the intricacies circumstances in various parts of the world, including in Indonesia, at least starting from post-Revolutionary Iran (tsaurat Iraniyyah $)^{9}$. Shia in origin is a group who follow Ali and Ahl-ul-Bait and his family to the extent mentioned that Ali was the imam after the Messenger, and those who are entitled to inherit the Caliphate ${ }^{10}$.

Before that, ordinary people only understand shia in general, that the Shia is one of the streams that has developed in the Islamic world, like other Islamic sects, but they do not know a lot what is actually shia, what are the cornerstone and the contents of teaching, aqidah and impressions in daily life. Iranian Revolution really opened the eyes of the world, and become the most powerful magnet that attracts the attention of the reviewers, academics and the scholars. Muslim communities in the world become interested to know more and more about Shi'ite.

The war of ideas within the framework of the ideology against a flow in religion, like Shi' ite actually much more difficult and complicated than argue mind-thoughts evangelists in the dialogue between religions, and this is because they use a secret weapon that is so memorable that taqiyyah. This is one picture from the point of the problems we are facing now, the conflicts that arise only between the Sunni and shia to this day has not ended, it therefore raised our curiosity is it true that all this background, it is very important to

\footnotetext{
${ }^{8}$ Muhammad Husain al-Zahabiy, al-Tafsir wal Mufassirun (Kairo: Maktabah Wahbah, 2000), 5.

9 Muhammad Husain al-Dzahabi, al-Tafsir Wa alMufassirun, Juz II (Kairo: Maktabah Wahbah, 2000), 3299.

${ }^{10}$ Muhammad Husain al-Zahabiy, al-Tafsir wal Mufassirun (Kairo: Maktabah Wahbah, 2000), 5.
} 
discuss, examine, shia is more comprehensive and holistic.

Muhammad Husain al-Dzahabi mentioned several comments of Shia more clearly. From Shia people of Imamiyah Ithna 'Asyara there include the interpretation of al-Hasan al-'Askari (d. 254 $\mathrm{H})$, tafseer of Muhammad ibn Mas'ud ibn Muhammad ibn' Iyasy al-Silmi al-Kufi (d. Century III $\mathrm{H}$ ), the interpretation of 'Ali bin Ibrahim al-Qummi (w. the beginning of the fourth century AH), al-Tibyan by Abu Ja'far Muhammad ibn al-Hasan ibn' Ali al-Tusi (d. 460 H), Majma 'al Bayan works of Abu Ali al-Fadlal bin al-Hasan al-Thabrasi (d. $538 \mathrm{H}$ ), al-Shafi works of Mala Muhsin al-Kasyi, Mir-at al-Anwar al-Asrar wa Misykat works of Abdul Latif al-Kazirani, Tafseer of al-Qur'an by Abdullah bin Mohammed Ridla al'Alawi (d. 1242 AH), Bayan al-Sa'adah fi maqamat al-'Ibadah work Sulthan bin Muhammad bin Haidar al-Khurasani (w. H XIV century), and Ala-u-al-Rahman fi Tafseer of alQur'an by Muhammad Jawad bin Hasan al-Najafi (d. 1352 H). From Shi'i people, Isma'ilism or Bathiniyah, both Mutaqadimin and Mutaakhirin, Imam al-Dhahabi did not mention clearly the work of arisen tafseer. Likewise from among Shiites of Babiyah and Bahaiyah. Because from these three streams of Shiites do not have many books of interpretations that were found, because the scholars from these circles were not focusing to write the book of tafseer. Furthermore, from among the Shiites of Zaydiyyah, there were some commentaries among them: Gharib al-Qur'an by Imam Zaid bin Ali, al-Tahdheeb work of Muhsin bin Muhammad bin al-Zaidi Karamah (d. 464 H), al-Taisir fi al-Tafsir work of Muhammad al-Hasan ibn al-Zaidi Nahawi (d. 791 H), Tafseer Ibn alAqdlam, Tafseer Ayat al-Ahkam works of Hasan ibn Ahmad al-Najari, Muntaha al-Maram work of Muhammad ibn al-Hasan ibn al-Qasim, and Fath al-Qadir al-Syaukani work $(\text { d. } 1250 \mathrm{H})^{11}$.

${ }_{11}$ Muhammad Husain al-Dzahabi, al-Tafsir Wa alMufassirun, Juz II (Kairo: Maktabah Wahbah, 2000), 3-299.
Shia's comments of Quraish Shihab can be seen in his work of Encyclopedia of Al-Qur'an: Vocabulary Study and Its Tafsser, in the book, he often uses the interpretation Shia Al Mizan essay writing of Thaba'thaba'i as a reference of his writing. Another example is the publication of the book: Sunna-Shiite Hand in Hand! Could it be? in this book is said, that the between-Shiite Sunnah there are similarities in the principles of the doctrine, there is a difference is in the details. But the equation is much more. It can be seen from the problem of faith in Allah and the Last Day, obedience to the Apostle and follow what is considered a legitimate source of his, as well as implementing the five pillars of Islam. In the book itself stated Abi Syi'ah Abdullah advised; "The real world and the hereafter belongs to the priest, who wished and given to the rejection of those who do not wants. This is the power given by God to the Imam. As written by Muhammad ibn al-Kulayni Yackub in the book Usul Kafi, especially in the chapter entitled "The Earth is a wholly-owned Imam". One Syicah other scholars, as-Sadiq Jacfar allegedly saying "It's got the earth is the Imam, the Imam out if you will be enough light (nur). Humans would not require the sun and moon. ${ }^{12}$."

In fact, Allah Subhanahu wa ta'ala says in the Qur'an, letter of Allah SWT in al-Araf 128:

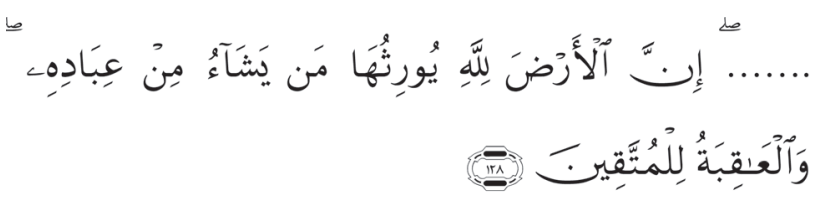

Meaning: "That is the truth, the earth belongs to Allah, passed on to whom He wills of His servants, and a good sequel is for those who fear Him”.

According to Quraish, in the language of Suni or Sunna means the behavior or actions of

${ }^{12}$ M.Quraish Shihab, Sunnah-Syi'ah Bergandengan Tangan, mungkinkah, 3 . 
the Prophet Muhammad. While Shia means "to follow", the point here is to be a follower of Prophet Muhammad. Therefore, "all Sunna is Shia, and all Shia is Sunna". Because those who follow the Prophet's behavior is his Messenger and vice versa. In fact, the meaning of Shia are followers (Ali bin Abi Talib ra). Quraish obviously have manipulated the meaning of Shia. If Sunnah and Shia has no difference, of course no need to acquaint themselves with different names.

\section{Table 1: Reference of Tafseer al-Mishbah}

\begin{tabular}{|c|c|c|c|}
\hline No & $\begin{array}{l}\text { Volume/ } \\
\text { Edition }\end{array}$ & Pages of Tafseer & Remarks \\
\hline 1 & Volume 1 & $18,61,196$ & 3 \\
\hline 2 & Volume 2 & $\begin{array}{l}180,223,259,336,444,486,487,498,542,567,618,721,730,799,802,803,809, \\
826\end{array}$ & 18 \\
\hline 3 & Volume 3 & $\begin{array}{l}180,223,259,336,444,486,487,498,542,567,618,721,730,799,802,803,809, \\
826\end{array}$ & 39 \\
\hline 4 & Volume 4 & $\begin{array}{l}9,17,19,39,45,55,62,71,82,108,122,136,139,141,164,172,202,205,215,218, \\
234,257,268,278,307,317,320,346,362,369,381,393,392,396,411,432, \\
435,469,492,496,498,501,510,556,560,594,599\end{array}$ & 47 \\
\hline 5 & Volume 5 & $\begin{array}{l}19,21,44,118,132,137,156,157,236,238,239,263,269,276,276,279,329,330, \\
342,388,396,428,432,439,505,522,540,542,543,544,559,565,567,570,582, \\
590,603,605,609,620,627,632,636,647,666,667,688,691,701,713,719,722, \\
724,734,737,743,745,750,758,761,766,769,770,787,788\end{array}$ & 65 \\
\hline 6 & Volume 6 & $\begin{array}{l}14,31,46,51,55,65,75,90,94,107,112,118,147,160,185,198,230,251,254, \\
260,279,305,312,347,359,361,368,379,385,386,387,396,402,420,464,493, \\
503,518,560,562,566,571,589,593,594,602,603,610,616,630,663,682,685, \\
690,692,705,712,714,726,734,754,756,767,770,773,775,777\end{array}$ & 67 \\
\hline 7 & Volume 7 & $\begin{array}{l}5,29,30,33,35,36,37,38,40,44,47,50,57,73,80,89,99,100,101,102,104, \\
106,108,114,121,132,133,134,158,174,175,177,182,182,183,194,197,207, \\
214,224,231,253,237,243,246,248,251,251,258,262,268,274,280,295,297, \\
303,312,319,327,332,340,341,356,362,370,371,372,376,377,384,389,393, \\
394,395,402,418,419,453,459,477,482,489,494,507,544,553,568,570,582, \\
597,603,605,631,652,660,673,680,689,697,707,708\end{array}$ & 102 \\
\hline 8 & Volume 8 & $\begin{array}{l}3,14,24,27,37,40,41,61,77,82,91,99,111,118,121,130,160,162,165,191, \\
197,198,225,237,264,285,288,294,296,302,313,321,337,343,355,392,393, \\
406,407,416,418,421,425,433,439,447,456,469,504,511,525,555,564,568 \\
574,619\end{array}$ & 56 \\
\hline 9 & Volume 9 & $\begin{array}{l}3,23,35,46,54,62,73,75,76,93,94,96,97,100,101,108,120,129,134,134, \\
137,139,147,153,171,179,188,196,203,205,206,208,210,243,250,264,265, \\
269,269,278,2297,332,343,351,355,360,366,376,388,395,415,427,432,440, \\
477,484,489,490,491,493,496,511,512,513,515,516,518,519,520,521,522, \\
524,536,557,561,562,562,567,576,590,595,614,623,635,636,642,646,647, \\
649,649,650,654,657,665,667,780,681,682,690,691,692 .\end{array}$ & 100 \\
\hline 10 & $\begin{array}{l}\text { Volume } \\
10\end{array}$ & $\begin{array}{l}4,42,43,53,64,68,85,87,88,90,91,95,133,138,148,159,193,196,198,212, \\
213,224,229,267,274,293,294,304,310,321,322,327,329,352,356,361,364, \\
375,385,390,392,418,445,482,487,496,534,548,550,557,604,606,614,626, \\
650,652,655\end{array}$ & 56 \\
\hline
\end{tabular}




\begin{tabular}{|c|c|c|c|}
\hline 11 & $\begin{array}{l}\text { Volume } \\
11\end{array}$ & $\begin{array}{l}3,8,13,27,35,52,61,68,71,77,82,83,85,87,92,112,113,114,119,126,131, \\
132,134,135,136,156,161,168,174,180,183,214,221,-, 222,228,230,244, \\
256,262,278,285,286,319,-, 322,328,344,345,363,382,392,422,430,237, \\
452,462,464,468,479,481,484,489,515,526,527,530,531,542,546,560,571, \\
577,580,586,588,589,603,625,659 .\end{array}$ & 78 \\
\hline 12 & $\begin{array}{l}\text { Volume } \\
12\end{array}$ & $\begin{array}{l}9,23,25,63,64,79,85,96,108,117,118,120,120,123,131,136,137,148,151, \\
160,164,173,185,191,197,203,207,225,227,241,248,251,270,282,319,334, \\
340,341,349,350,371,381,389,390,407,408,411,421,438,442,496,505,507, \\
554,557,568,577,578,600,612,613,626,627\end{array}$ & 62 \\
\hline 13 & $\begin{array}{l}\text { Volume } \\
13\end{array}$ & $\begin{array}{l}3,11,12,25,39,50,61,68,76,102,108,109,-, 110,-, 119,127,135,136,140, \\
160,173,198,207,208,212,222,224,--, 226,229,244,-, 245,270,274,277,278, \\
279,282,293,297,298,-, 300,318,-, 338,346,354,361,362,369,371,381,385, \\
396,402,413,414,422,433,436,437,-, 439,440,441,443,452,458,484,507, \\
509,513,514,518,536,537,549,552,589,591,606,611\end{array}$ & 78 \\
\hline 14 & $\begin{array}{l}\text { Volume } \\
14\end{array}$ & $\begin{array}{l}12,17,20,22,25,28,35,39,44,48,54,69,95,107,112,116,121,146,154,172, \\
178,181,192,197,201,206,218,226,235,282,289,312,319,321,322,335,341, \\
342,348,358,379,380,392,516,530,569,586\end{array}$ & 47 \\
\hline 15 & $\begin{array}{l}\text { Volume } \\
15\end{array}$ & $\begin{array}{l}19,20,20,28,29,60,62,68,71,73,74,82,84,98,111,130,147,167,182,190, \\
192,269,272,272,281,292,339,343,345,367,369,451,499,506,513,531,546, \\
560,574,661,663,696 .=43\end{array}$ & 43 \\
\hline
\end{tabular}

Source: Dissertation (doctoral) Afrizal Nur (Malaysia: UKM, 2013).

\section{Brief Biography of M. Quraish Shihab}

M. Quraish Shihab (hereinafter referred to Quraish), with full name of Muhammad Quraish Shihab, was born in the district of Sindenreng Rappang (Sindrap) South Sulawesi on $16^{\text {th }}$ February 1944. He came from a humble family and held a very good belief on religion. His father of Habib Abdurrahman Shihab (1905-1986) was a scholar of Tafseer, former Rector (Chancellor) of State Islamic Institute (IAIN) of Alaudin Makassar, South Sulawesi (1972-1977), his father (Abdurrahman Shihab) has studied religion from childhood and become a preacher. In addition, he was also a merchant. At the end of his life, he spent more time on the service in education, namely by participating in establishing UMI (Universitas Muslim Indonesia) in Ujung Pandang and become leader (1959-1965). Since childhood, Quraish Shihab had been exposed and educated by his father to love the Qur'an. When he was six, his father required them to follow the teachings of the Koran held by his own father. Beside asking Quraish Shihab to read Qur'an, his father also briefly told the stories in the Koran. Starting from here, Shihab's seeds of love to holy book of Allah Swt began to grow.

Shihab's father was very close to all groups and communities so that the flow could be accepted by various groups of Muslims, and even nonMuslims, because he was such a high tolerance. His father who always stressed to Shihab that the more extensive knowledge of a person, the greater the tolerance, and he also always stressed that there is no one group that monopolize the truth or falsity. All can be wrong and can correct, except for Allah and His Messenger, as if the apostle wrong, then God immediately rebuked. ${ }^{13}$

In his life, he was accompanied by a wife named Fatmawati and with 5 children, each named Najeela, Najwa, Nasyawa, Nahla and Ahmad ${ }^{14}$.

\footnotetext{
${ }^{13}$ M. Quraish Shihab, Sunnah Syi'ah Bergandengan Tangan, Mungkinkah (Jakarta: Lentera Hati, 2007), 2.

${ }^{14}$ M. Quraish Shihab, Menyingkap Tabir Ilahi, Asma alHusna dalam Perspektif al-Qur'an (Jakarta: Lentera Hati, 2001).
} 
Traditionally though he was born outside the island of Java, but the tradition of Quraish Shihab family was Nahdiyyin. Moreover, after completing his education at the basic level in Ujung Pandang, he was sent to Boarding School of Darul Hadith al-Faqihiyyah Malang, East Java, with Al-Habib Abdul Qadir Bilfaqih (born in Tarim Hadhramaut, Yemen, on 15 Safar 1316H, and died in Malang, East Java on 21 End of Jumadil of $1382 \mathrm{H}, 1962 \mathrm{M}$ coincided with 19 November) he was a great scholar with very broad minded and always instill in all students a sense of humility, tolerance, and love of Ahl al-Bait, breadth of insight, make he was not fixated on one idea. ${ }^{15}$

While he had been in boarding school of Darul Hadith for two years, Quraish learned in the boarding school during morning and followed the lessons at school at dusk. In this boarding school, Quraish were introduced more deeply with the tradition of Nahdlatul Ulama (NU), studied Arabic and various other religious disciplines. In 1958, after completing the education, Shihab went to Cairo, Egypt became the representative of South Sulawesi in the national selection organized by the Ministry of Religious Affairs of the Republic of Indonesia. He set out with two of his brothers Umar Shihab and Alwi Shihab, and scholarships received assistance from local governments (LGs) of South Sulawesi. He studied at the Department of Tafseer (Interpretation) at the Faculty of Ushuluddin of University of alAzhar, but previously also studied at the level of tsanawiyah in this pyramid country.

When his score in Arabic language at the secondary level did not meet the requirements to continue his sermons on department of Tafsir Hadith, he wanted to repeat a year in order to study Arabic more although basically his score of the Arabic language has met the condition for entering

${ }^{15}$ M.Quraish Shihab, Sunnah-Syi'ah Bergandengan Tangan, mungkinkah, 3. another position at the University of al-Azhar University Darul mahupun Ulum, but he did not use that opportunity because his interest to explore the field of study Tafseer of al-Qur'an in al-Azhar.

During a student at al-Azhar, he was too much involved and active in the Egyptian branch of the Indonesian Student Association, he also expanded interaction especially with the number of students who came from other countries, according to him other than to broaden thinking mainly about other nations also can consolidate foreign languages, especially Arabic. ${ }^{16}$

In 1967 he got Lc (S-1) at the Faculty of Ushuluddin in the department of Tafsir and Hadith of al-Azhar University. Then he continued his studies at the same faculty and in 1969 earned MA, with a thesis entitled 'al-I'jaz al-Tasyri'iy li al-Qur'an al-Karim"17

In Egypt, the Quraish learned a lot with great scholars such as Shaykh Abdul Halim Mahmud, author of "al-Tafsir al-Falsafi fi alIslam", and "al-Islam wa al-Aql", "Biography Ulama Sufism" and others. Abdul Halim Mahmud is also the advisor of Quraish while studying at the University of al-Azhar. The teacher also graduated from Al-Azhar University and then continued his sermons to the Sorbon University in the field of philosophy. Quraish claimed his impression to the teacher: "He was my professor who later became the Sheikh of Al-Azhar, I often ride the bus with him, he had a great influence"18.

During his study in Egypt, he was an industrious and diligent student as well as reading a lot. Among the books that made him interested was the book of Abbas Mahmud al-Aqqad. According to his testimony, the books written by scholars strongly influenced and formed his personality, because he had all books of Abbas

\footnotetext{
${ }^{16}$ Ibid., 12.

${ }^{17}$ M. Quraish Shihab, Membumikan al-Qur'an: Fungsi dan Peran Wahyu dalam Kehidupan Masyarakat (Bandung: Mizan, 1996).

${ }^{18}$ Miftahudin bin Kamil, 2007.
} 
Mahmud al-Aqqad, and according to Quraish: "His views (Abbas Mahmud al-Aqqad) was rational but in the future the same was on the line, did not deviate". After he got his Master, then returned to Indonesia (Makassar), when asked why he did not immediately proceed to the $\mathrm{PhD}$ program, he replied: "THAT would be more mature when he taught first before taking doctoral program and will get a lot of experience, he felt that beside this was too long to stay in Egypt and had wanted submissive to society, settle down and had children ${ }^{19}$.

At the age of 25 years he gained the trust become a lecturer at IAIN Alauddin, Ujung Pandang, and from 1973 to 1980 hold a position as vice-Rector of Academic and Student Affairs at IAIN Alauddin, Ujung Pandang. In addition, he was also assigned to other positions, within the campus he became the Coordinator of Private Universities (Kopertis Region VII East Parts of Indonesia), while beyond campus he was appointed as eastern Indonesian Police Chief assistant in the field of Mental Development (BIMTAL). While he was there, he was also active in various investigation such as, "Application of Life Religious Harmony in eastern Indonesia" (1975) and Endowments Problems at South Sulawesi “(1978). ${ }^{20}$

In 1980, Quraish returned to Cairo, Egypt to continue his studies at the University of alAzhar. In 1982 through his thesis entitled "Nazham al-Durar li al-Baqa'i: 'tahqiq wa Dirasah". He got Doctor of Philosophy $(\mathrm{PhD})$ in the field of sciences of the Qur'an with brilliant Summa cum Laude award, and then was accompanied by the first rank (Mumtaz ma ' $a$ dignity al-ataraf al-ula). With the achievement, he was recorded as the first from Southeast Asia who holds a PhD in the sciences of the Qur'an from the University of al-Azhar, Egypt.

\footnotetext{
${ }^{19}$ Ibid., 29.

${ }^{20}$ M. Quraish Shihab, Membumikan al-Qur'an: Fungsi dan Peran Wahyu dalam Kehidupan Masyarakat.
}

Overall Quraish had undergone intellectual development under the care and guidance of Al-Azhar University for more or less than 13 years, almost certainly that the climate and scientific tradition in Islamic studies at AlAzhar University environment has certain effects on the intellectual trends and patterns of thought of Quraish. Thus in order to obtain a clearer understanding of the intellectual trends and patterns of religious thought of Quraish, especially dimensional of interpretation, and this should be investigated even if only in general, climate and tradition of knowledge in Islamic studies at alAzhar University, which became the intellectual development and science.

\section{Note of Shia teachings in Tafsir al-Mishbah}

Citing what is presented in the introduction to his book of Sunnah of Shia Shaking Hand! Could it be?, he stated: "The scientific mandate demands to convey what it is believed, worried with lest silence, considered Allah hide the truth". Running it is an important scientific mandate by the authors make this thesis in order to carry out preventive measures to prevent the damage of muslim's aqidah. The segment interpretation of shia in the interpretation of al-Mishbah are:

\section{To idolize the daughter of Prophet Muhammad (Fatimah ra)}

Quraish interprets Article 38 of surah al-Ma'idah, he strengthens the interpretation of the hadith below:

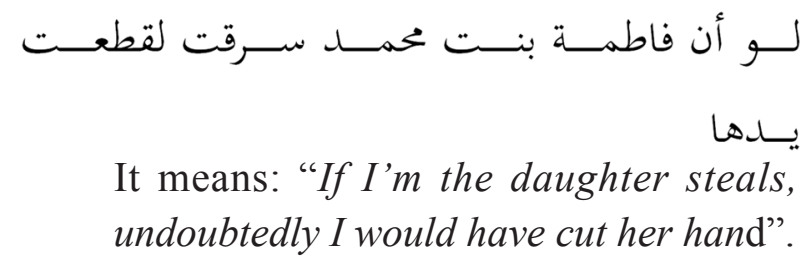

But there is something unusual from the Quraish that when he did not mention the name "Fatima" in the hadith translation, but hide the name of Fatimah as an indication that Quraish embraced Syi' ah Twelver sect. Here is a translation of the Quraish towards Matan 
above hadith:

\section{"If the A steal, undoubtedly will surely} have cut his hand".

Quraish said: "This hadeeth of the Prophet in the name of a very noble. Author (Quraish) is reluctant to write because although this hadith is about the "assumption", but makes the assumption that something unnatural spoken except by the Prophet himself, as revealed by M.Quraish Shihab.

\section{Ali bin Abi Talib ra is People First Substitute of the Prophet}

M. Quraish Shihab interpret paragraph 67 of surah al-Ma'idah:

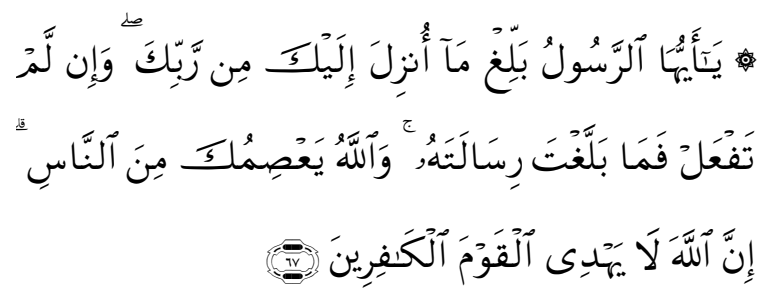

Meaning: "O Messenger of Allah, tell what has been revealed to you from your Lord, and if not you do not do it (by giving it all), then none of you is conveying His mission and Allah also that will take care of you from (evil) human. Verily Allah does not guide the unbelievers guidance".

Quraish bring Thaba'thaba'i opinion: "It is ordered to be delivered the issue of the position of Ali Ibn Abi Talib ra as trustee and his successor in religious and mundane. This is just he gave at Ghadir Khum after performing Hajj Wada '. And that's why he was called by the title of apostle, because that's the most appropriate title with the content of what is to be delivered this. In the qacidah tarjih associated with Atsar said: "Interpretation of the Salaf jumhur be prioritized/precedence of interpretation syaz".

Based on this kaedah, Quraish should prioritize quote from the scholars of the Salaf than other muffassirs like Thaba'ithaba'i. According to Abu Bakr Jabir al-Jazaeri This paragraph describes the necessity of the Apostles convey his treatise, by the Messenger Muhammad SAW execute this command from God in this matter is a matter that must to be enhanced. No sheikh al-Jazaeiri explain that Ali bin abi Talib is a replacement after Muhammad saw.

Syaikh Adurrahman Nasir bin as-Sa'di argues: "This verse is the command of Allah to the Prophet in the form of an order which is great, and glorious, that convey the revelation from Allah SWT related to 'Aqeedah, deeds, syara' legal and other Allah's commands. The Prophet delivered perfectly all of these cases, in the form of speeches, giving good news and scary news, so they all became a cadre of scholars Robbani so that they become the most important people like the radiallahu anhu companions and succeeding generations.

3. Mukminin people in verse 105 of alTawbah letter are special people

Quraish was very often cite mufassir Shiah of Thaba'ithaba'i, more than 800 times the quote Quraysh against Thabacthabaci in his tafsir al-Mishbah. Professor Ramli Abdul Wahid stated: "When I was a student of M.Quraish Shihab in IAIN Syarif Hidayatullah Jakarta (now UIN Syarif Hidayatullah Jakarta), he (Quraish) once said in his forum with me:" in that we must refer to two figures Shia namely Abu Ja'far Muhammad ibn Hasan at-Tussi $(460 \mathrm{H})$ and Thaba'thaba'i, because these two figures according to Quraish were very scientific figures".

Surely however its scientific and objective Thaba'ithaba'i mentioned by the Quraish, his subjectivity least can not be hidden. When Quraish citing Thaba'thaba'i interpretation at paragraph 105 of surah alTawbah following: 


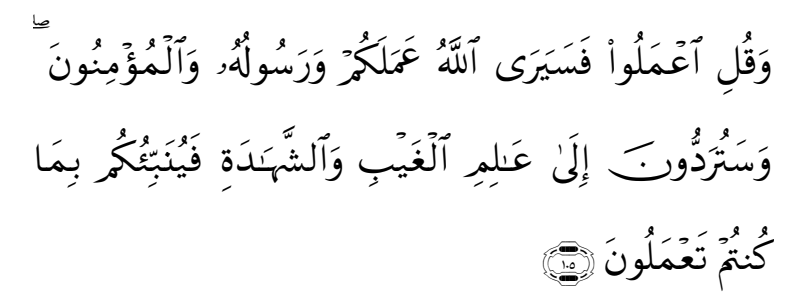

It means: "Say (Hi Muhammad): "Have great character you (will any of the commands), then Allah and His messenger and the believers will see what you do, and you will be returned to Allah the AllKnowing judge actions supernatural and real, then He 'll explain to you what you do".

Thaba'ithaba'i argues that word "almu'minin" not all the believers, but the special people that serves as a martyr, namely witnesses human charity. Unfortunately, this Shia Mufassir does not explain what that basically says al-believers here is limited to certain people, not all of the believers.

If we look at the interpretation of Sunni scholars, such as Muhammad Ali as-Shobuniy, he stated: This paragraph uses the injunction which contains the promise of Allah, namely do deeds what you like from some amaliah, verily deeds that you do not will not secreted by Allah, and all deeds will be showed on the Day of Judgement to the Messenger and the believers.

The same interpretation put forward by Abdurrahman bin Nasir al-Sa'diy and Abu Bakr al-Jazaeiriy. As a conclusion, no asShobuniy, A1-Sa'diy, A1-Jazeiriy interpret believers in this verse with special people or those options.

\section{4. "Ahl al-Bait"}

When interpreting verse 33 of Surah al-Ahzab:

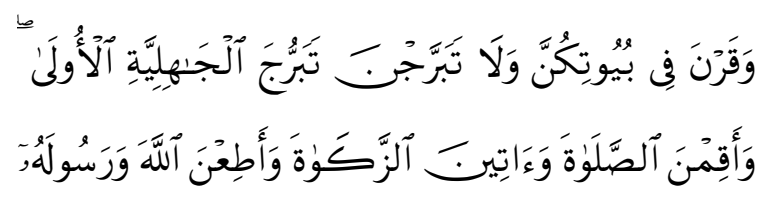

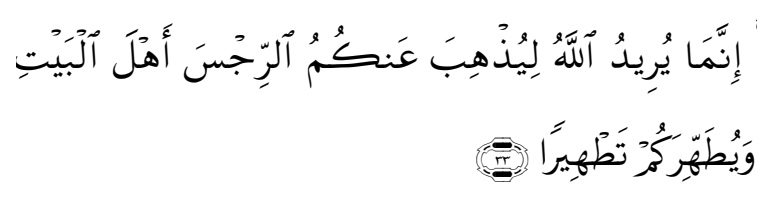

Meaning: "And you shall remain silent at your home, and do not expose yourself like that done by the jahiliyyah in old era, and establish prayer and give zakah and obey in Allah and His Messenger. Verily Allah ask you with everything that just because want to delete cases that contaminates you-O Ahlul Bait, and you want to clean a thorough cleansing (of all that is vile)".

In addition to the expression of feqah scholars such as Imam Malik and Abu Hanifah about who our other included "Ahlul Bait" in this paragraph, Quraish also explained opinion of Thaba' Thaba'i with following expression:

"Famous shia scholar, Thaba 'Ahl-ul-Bait thaba'i is limiting sense in this paragraph is limited to five people entering into the hood, the Prophet Muhammad, Ali Ibn Abi Talib, Fatimah Az-Zahra, as well as al-Hasan and al-Husain. While their cleansing words from sin and consecration they understood in the meaning of "ismat", namely the continuance them from sin".

According to Ibn Jarir al-Tabariy word "liyuzhiba Ankum ar-rijsa" contains the following understanding:

1. Crime and disobey, so Allah purify them from the dirt

2. Satan

3. Conduct Shirk

While the coverage of "Ahlul bait" are: Ali, Fatimah, Hasan and Husein and the wives of Rasulullah saw, as Imam at-Tabariy explains in his tafseer. Abu Bakr al-Jazaeriy writes in his commentary: "from ignorance group "Rafidah" which establishes a decision that does not comply with the decision of Muslims globally are with 
their decision restricting ahlu al-Bait simply Ali, Fatimah, Hasan and Husein and does not include the wives of the Prophet. Muhammad Ali asShobuniy states ahlul bait is "ahl al-bait alnubuwwah" or family of prophet.

Ibn Kathir writes in his commentary: "This paragraph bahawasannya determine the entry of wives of the Prophet in the Ahlul Bait, because they cause a decrease in this paragraph. Many hadiths indicate where the Ahl-ul-Bait referred to in this paragraph is generally accepted. Among the hadiths it is:

1. Hadith narrated by Imam Ahmad Anas bin Malik said: "Messenger of Allah through the door of Fatimah ra for six months, if he is out for Fajr prayer, saying:

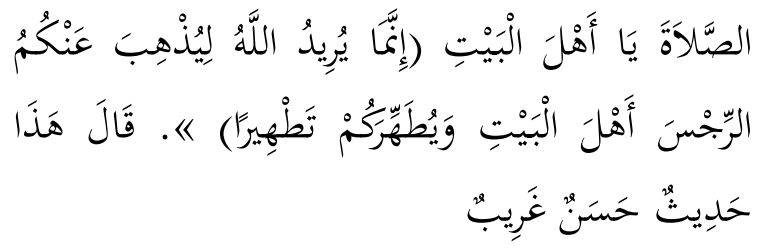

"Prayer, Hi Ahlul-Bait, Verily Allah Swt intends going to eliminate sin from you,

Hi Ahlul Bait and clean you as clean-net".

2. Ibn Jarir narrated that Safiayyah bint Shaybah said: "One morning the Prophet came out with a piece of cloth woven from black hair. Then Hasan ra came and entered with him, then came Husein ra and entered with him. Then Fatimah ra came and inclusion with him. Then Ali ra came and entered with him. Then the Messenger of Allah said:

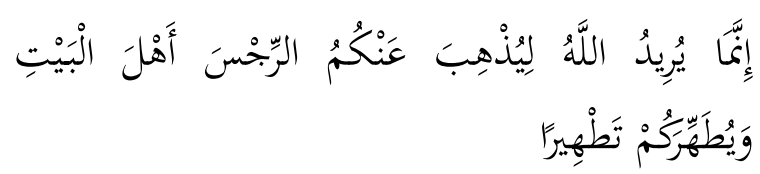

This means: "Verily Allah intends going to eliminate sin from you, Hi Ahlul Bait and clean you as clean-net".

He gives suggestions and encouraged to adhere to Kitabullah. Then he said: "And my Ahlul Baitiku, I remind you to Allah about Ahlul Baitiku, I remind you to Ahlul Baitiku about Ahlul Baitiku (He said it as much as three times).

Husein then asked: "Who are his Ahlu Bait ya Yazid?" Are his wives included his Ahlu Bait? He replied: "His wives are his Ahlu Baiti. However, his Ahlu Baiti are his family whos are forbidden to receive Sadaqah ". He asked again: "Who are they"? He replied: "They are a family of Ali, the family' of Aqil, the family of Ja'far and the family of Abbas ra". he asked: "they all are forbidden to get shadaqah afterwards? He replied: "yes".

Then there is no doubt in it, that the person who wants to reflect on al-Qur'an, he will find that wives of Muhammad saw into the word of Allah:

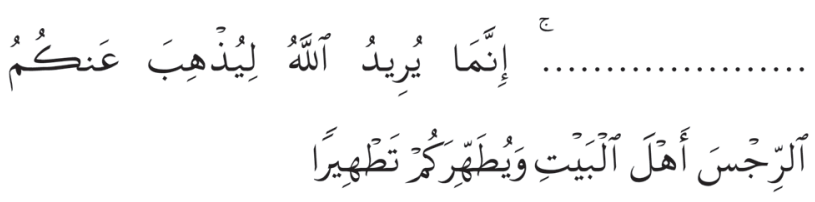

Table 2: Table of Reference of M.Quraish Shihab Against Shiite figures

\begin{tabular}{|c|l|l|l|}
\hline No & \multicolumn{1}{|c|}{ Figures Name } & \multicolumn{1}{c|}{ Reference } & \multicolumn{1}{c|}{ Description } \\
\hline 1 & Al-'Alamah Thaba'thaba'i & Al-Mizan & 861 cites \\
\hline 2 & Imam Jacfar al-Shadiq (w 184H) & Hadits & 2 cites \\
\hline 3 & Al-Thabarsiy (w.538H) & Majma al-Bayan & Volume 14, p.139 \\
\hline 4 & M. Baqir al Sadr & Al- Maudhu i & Volume 1 p. 52 \\
\hline 5 & Murthada Muthahari & Nizham Huquq al-Mar'ah & Volume 2 p. 513/ Volume 15 p.594 \\
\hline 6 & M. Baqir al-Sadar & No written & Volume 15 p.467 \\
\hline
\end{tabular}

Source: Dissertation of Afrizal Nur (Malaysia: UKM, 2013), 100. 


\section{Conclusion}

To have studies in order to understand alQur'an, teach and deliver it to the community is a noble and sublime work, because science of Koran that is extremely high is Tafseer (hermeneutics).

The author has conducted a study on the influential cleric in Indonesia which has a high spirit and excellent scientific capabilities in the field of Qur'an and its interpretation, he is Muhammad Quraish Shihab. The study was focused on infiltration and al-Dakhiil dimensions that have been formulated by Syamir Abdul Aziz, Abdul Wahab al-Fayyid and others, namely Shi' ite interpretations.

This tafseer was written in the era of reform (1998), at the time opportunity and chance to obtain information from a diversity of sources of referral was open. Along with the development of science and technology, it was more or less to bring influence to the content of interpretation. The new shades of interpretation emerged in this century (including the Tafsir al-Mishbah) charged ilmi (scientific), philosophy oriented, inclusive, liberal, and often violate principles of Tafsir agreed by jumhur Ulama of interpretation performed by M.Quraish Shihab potentially makes different interpretation among the community as the largest user of interpretation of al-Mishbah in Indonesia, because he often uses controversy references. The findings are as follows First author: Ali bin Abi Talib ra is the first replacement of the Prophet, second: cult a lot the Prophet Muhammad's daughter Fatimah ra, third:

believers in paragraph 105 surat al-Tawbah are special people, fourth: controversy about the "Ahl al-Bait".

\section{Bibliography}

al-Dzahabi, Muhammad Husein. al-Tafsîr wa al-Mufassirûn. Juz II. Kairo: Maktabah Wahbah, 2000

Fayyad, Abdul Wahab. al-Dakhiil fi Tafsir alQur'an. Mesir: Maktabah Hasan, 1978.

M. Quraish Shihab. Membumikan al-Qur'an: Fungsi dan Peran Wahyu dalam Kehidupan Masyarakat. Bandung: Mizan, 1996.

-. Menyingkap Tabir Ilahi, Asma alHusna dalam Perspektif al-Qur'an. Jakarta: Lentera Hati, 2001.

- Sunnah Syi'ah Bergandengan Tangan, Mungkinkah. Jakarta: Lentera Hati, 2007. Mohd Nazri Ahmad. Isra 'iliyyat dan Pengaruh dalam Kitab Tafsir. Kuala Lumpur: Sanon Printing, 2004.

Moosa, Ahmed Syahaat Ahmed. Ad dakhiil fii At Tafsiir. Kairo: t.p, t.th. 